〈教育講演：老年病の診断と治療 $>$

\title{
老年者不整脈の診断と治療
}

\author{
上田 慶二 \\ Key words：洞不全症候群，ペースメーカー療法，心房細動，ワーファリン，抗不整脈薬
}

(Jpn. J. Geriat 28：292-294, 1991)

老年者の不整脈の診療に際しては，治療の対象とな る不整脈を選定することと老年者の病態に則した治療 を行らことが重要である。

以下に老年者に多くみられる重要な不整脈について 診断と治療上のポイントを示す。

\section{I. 不整脈の頻度}

老年者では日常診療に用いられる12誘導心電図にお いても高頻度に不整脈が検出される。東京都養育院老 人ホームの居住者 $(1,416$ 例, 平均年齢 76.5 歳) の健康 診断時の心電図検查に扮いて $35.7 \%$ の例に抢いて不整 脈が認められている。

健常老年者に损いても不整脈の頻度がホルター心電 因法により高率であることが認められている1 . 運動 負荷 ${ }^{201} \mathrm{Tl}$ 心筋シンチにより潜在性冠動脈疾患の除外 にも配慮した Fleg らの成績 ${ }^{2}$ においては上室性不整 脈が $88 \%$ ，心室性不整脈が $80 \%$ に報告されている。

老年者においては心臓刺激伝導系細胞の線維化や細 胞数の減少に加え, 老年期に増加する種々の心疾患や 高血压などに伴う負荷, 心筋病変の存在などが不整脈 の頻度の増大に関与している。したがって不整脈の頻 度は加齢とともに増大し，さらに心疾患の合併により さらに増大する。

\section{II. 不整脈診断上の問題}

老年者の不整脈には治療の対象とならない不整脈も 多いので不整脈の診断に際しては常に治療の要否の判 断が重要である。これらの判断に際して老慮されるべ き項目は, 不整脈の種類, 頻度とその重症度, 自覚症 状の有無, 基礎心疾患の有無とその治療状態, 電解質 濃度異常の有無などであるが，また薬物(ジギタリス， $\beta$ ブロッカー,カルシウム拮抗薬)などが老年者におい

Diagnosis and Therapy of Cardiac Arrhythmias in the Elderly

K. Ueda：東京都老人医療センター内科
て不整脈を生じ易いことも十分に配慮すべきである。 老年者にみられる動悸やふらつき，失神などの訴えに 際しても不整脈の関与を慎重に検討すべきであり，木 ルター心電図の活用が有用である。ささらに適応のある 例については電気生理学的検査法による詳細な検討が 治療法の選定に資する。

\section{III. 洞不全症候群とペースメーカー療法}

洞不全症候群は老年者に頻度の高い徐脈性不整脈で あり,ペースメーカー療法が有効であるが, 治療成績 の向上のためペースメーカー療法に際しさらに慎重な 配慮が必要である。

ペースメーカー植込み術を施行した老年者洞不全症 候群例の生存率は非植込例に比し有意に優れ，一般老 年人口の生存率に近似する ${ }^{3}$. しかし洞不全症候群(こ とに徐脈・頻脈症候群）に抢いてはぺースメーカー植 込み後にも発作性心房細動がみられることがしばしば あり，その後に固定性心房細動や脳塞栓症を合併する 危険がある。これら心房細動や脳塞栓症の発生は老年 者に扔いてもペースメーカーのペーシングモードに関 連し，心室抑制モード(VVI)にて多く，心房抑制モ一 ド（AAI），あるいは心房・心室ペーシングモード (DDD)にて減少する4). VVIはAAI や DDD に比し植 込夕操作が容易, 簡便であり, 多く使用されたが，血 行力学的改善や脳塞栓症の予防効果などをも考慮し AAI, DDD やさらに rate responsive ペースメーカー の植込みを積極的に行らべきである。

これらペースメーカー植込み例においては術後ホル タ一心電図検査を反復し, 発作性心房細動の発生に留 意する必要がある，発作性心房細動を反復する例にお いては抗不整脈薬の投与を行い，無効例については抗 凝血薬療法の適応についても検討すべきである。

\section{IV. 心房細動と抗塞栓療法}

心房細動は老年者の約 $10 \%$ にられ，心疾患例にお 
いては20～30\%に達する。老年者においては心房細動 例に占めるリウマチ性僧帽弁疾患の割合は小であり， 非炎症性弁膜症，虚血性心疾患，高血圧性心疾患，慢 性閉塞性肺疾患などの関与が大であり，稀に孤立性心 房細動と考えられる例がみられる。

これらの発作性, あるいは固定性心房細動の問題点 の 1 つして塞栓症の合併がある。老年者の心房細動 において塞栓症を生じる頻度について Peterson らは 発作性心房細動例にて $2 \% /$ patient•year, 固定性心房 細動に移行した例にて $4 \%$ としており，Flegel らの成 績では脳塞栓の発生率が7.9\%/patient・year であり， 危険因子として75歳以上の高齢之高血圧を挙げてい る。著者らの養育院老人ホームを主体とした心疾患を 合併しない心房細動例（平均年齢70.8歳）に打ける塞 栓発生率は2.1\%/patient・yearであった，以上より老 年者の非リウマチ性心房細動における塞栓発生率は 2 〜 $5 \%$ と推測され, high risk 群においてはより高い発 生率が予測される。

心房細動における塞栓の一次予防法に関する成績の 報告は少ないが, Peterson ら5はAFASAK studyに 打いて warfarin 療法のみが Placebo に比し有効であ り, aspirin は無効であったと報告している。またボス トングループも低用量の warfarin 療法が安全性も高 く, 非治療群, あるいは aspirin 群に比し塞栓予防に有 効であるとしている6).

これらの成績に基づき考察すると，心筋梗塞，高血 王性心疾患，洞不全症候群，心筋症，甲状腺機能六進 症などの塞栓の危険因子と考えられる病態を合併する 老年者非リウマチ性心房細動に対しては原則として warfarin 療法を検討すべきであると思われる。しかし 老年者ではwarfarin 療法が禁忌，あるいはその的確 な実施が困難な例も多く，かかる例に対しては血小板 機能抑制薬の投与に頼らざるを得ないが，その有効性 についてはなお不明であり, 今後の検討が必要である。

\section{V. 頻脈性不整脈の治療上の留意点}

頻脈性不整脈の治療の原則は成人例と異ならない が，老年者の病態に応じた配慮が必要である。

発作性上室性頻脈 (PSVT) は老年者において心筋虚 血，血圧低下や心不全を招くことが多いので，速やか な停止が必要である.PSVTの治療としてまず種々の 迷走神経刺激法が試みられるべきであるが，その方法 のらち眼球圧迫法は眼圧の異常上昇をみる恐れがあ り，老年者においては避けるべきである。薬物療法と
しての第 1 選択は verapamil 静注法であり, 次いで diltiazem, digoxin, propranolol が用いられる. Adenosine, ATP 製剤の静注も有効であるが, 老年者 においては房室伝導の抑制に加え洞結節機能の抑制が 強くみられることが多く，慎重な投与が望まれる。

心室性頻脈性不整脈の治療に関しては，まず症状の 有無, 血行力学に及ぼす影響と不整脈の生命予後に及 ぽす影響より治療の適応を慎重に判断すべきであり, 例えば無症状の散発性心室性期外収縮などに対して は，急性心筇梗塞の場合を除き抗不整脈薬による治療 は原則として不要であろら。米国の $\mathrm{CAST}^{7}$ に示され た如く抗不整脈薬の種類によっては, 危険な催不整脈 作用や他の副作用を示すことが予測される。

次いで治療の適応がある場合には抗不整脈薬の選択 の問題が生じる. 現在数多くのいわゆる抗不整脈薬が 用いられて居り，基礎心疾患や病態により適切な薬が 選択されるべきであるが，原則として IA 群により治 療を開始し, 無効な場合にはIB 群を, さらにIA 群十 IB 群の併用療法が試みられるのが妥当であると考兄 られる。ささにこれらの薬物が無効である場合には IC 群が用いられる。また運動や精神興奮に伴い発生する 心室性不整脈に対してはII群( $\beta$ ブロッカー)も用いら れる。

老年者においては肝藏においての代謝遅延や腎臓に よる排泄障害がみられるため, 薬物の血中濃度が高值 を示し，体内蓄積が生じらるので副作用を避けるため 用量の減量や投与回数の減少を計る必要がある場合が ある。また抗不整脈薬の催不整脈作用にも十分に配慮 し, 副作用の懸念される例に対しては入院のもとで治 療を開始することが望ましい。

\section{文献}

1）橋場邦武：老年者の不整脈。日老医誌 26 : 101-109, 1989.

2) Fleg JL, Kennedy HL: Cardiac arrhythmias in healthy elderly population detected by 24 hour ambulatory electrocardiography. Chest 81: 302-307, 1982.

3）大川真一郎, 藤森尚子, 渡辺千鶴子, 上田慶二：老 年者ペースメーカー植え込み例における生命予後 と生活予後. 心臟ペーシング 5：90-96, 1989 .

4）千田宏司, 大川真一郎, 今井 保, 塚崎富雄, 高野 幸一, 渡辺文督, 星野 智, 渡辺千鶴子, 上田慶二： 老年者洞不全症候群 (SSS 例)の予後の検討，特に 
心房細動抑制効果と塞栓予防効果に対する生理的 ペーシングと心室ペーシングの比較検討. 第 5 回 日本心臓ペーシング学会学術大会にて発表, 1990 年, 5 月.

5) Peterson P, Boysen G, Godtfredsen J, Andersen ED, Andersen B : Placebo-controlled, randomized trial of warfarin and aspirin for prevention of thromboembolic complications in chronic atrial fibrillation. The Copenhagen AFASAK Study. Lancet 1: 175-179, 1989.

6) The Boston Area Anticoagulation Trial for
Atrial Fibrillation Investigators: The effect of low-dose warfarin on the risk of stroke in patients with nonrheumatic atrial fibrillation. N Engl J Med 323 : 1505-1511, 1990.

7) The Cardiac Arrhythmia Suppression Trial (CAST) Investigators: Preliminary report: Effect of encainide and flecainide on mortality in a randomized trial of arrhythmia suppression after myocardial infarction. $\mathrm{N}$ Engl J Med $321: 406-412,1989$ 